\title{
On the Ocean Sunfishes (Mola mola, Linnaeus 1758) By-Caught Off the Mediterranean Coast of the Gaza Strip, Palestine
}

\author{
Abdel Fattah N Abd Rabou ${ }^{1 *}$, Mohammed R Al Agha², Mohammed A Abd Rabou ${ }^{2,3}$, Mazen T \\ Abualtayef ${ }^{4}$, Kamal J Elnabris ${ }^{1}$, Kamal E Elkahlout ${ }^{1}$, Tarek A El Bashiti ${ }^{1}$, Huda E Abu Amra ${ }^{5}$, Adel \\ J Attallah ${ }^{6}$, Hassan G Abu Hatab ${ }^{6}$ and Mohammed A Aboutair ${ }^{6}$ \\ ${ }^{1}$ Department of Biology and Biotechnology, Islamic University of Gaza, Palestine
}

${ }^{2}$ Department of Environment and Earth Sciences, Islamic University of Gaza, Palestine

${ }^{3}$ Department of Information Technology, University College of Applied Sciences, Palestine

${ }^{4}$ Department of Environmental Engineering, Islamic University of Gaza, Palestine

${ }^{5}$ Department of Biology, Al-Aqsa University, Palestine

${ }^{6}$ Directorate General of Fisheries, Ministry of Agriculture, Palestine

*Corresponding author: Abdel Fattah N Abd Rabou, Department of Biology and Biotechnology, Islamic University of

Gaza, Palestine

\section{ARTICLE INFO}

Received: 㠅 August 05, 2020

Published: 幽 August 20, 2020

Citation: Abdel Fattah N Abd Rabou, Mohammed R Al-Agha, Mohammed A Abd Rabou, Mazen T Abualtayef, Kamal J Elnabris, et al., On the Ocean Sunfishes (Mola mola, Linnaeus 1758) By-Caught Off the Mediterranean Coast of the Gaza Strip, Palestine. Biomed J Sci \& Tech Res 29(4)2020. BJSTR. MS.ID.004831.

Keywords: Ocean Sunfish; Mola mola; Mediterranean Coast; By-catch; Threats; Gaza Strip; Palestine

\section{ABSTRACT}

The Ocean Sunfish (Mola mola, Linnaeus 1758) is the heaviest and largest bony fish worldwide. It is frequently recorded in the marine waters around the world including the Mediterranean Sea. The current descriptive paper, which extended for 15 years starting from 2006 to 2020, comes to provide information on Ocean Sunfishes caught off the Mediterranean coast of the Gaza Strip, Palestine. Frequent visits to the Gaza coast on the Mediterranean Sea, meetings and discussion with stakeholders and chasing of media reports were main and capital tools used throughout the study. On-site preliminary morphometric characters of Ocean Sunfishes were measured as well. At least, 20 specimens of the species were known to be separately caught off the Mediterranean coast of the Gaza Strip by drift gill net fisheries since 2006. The heaviest specimen was recorded in December 12, 2006. It had about 2.8 meters as a total length starting from the head to the pseudo-tail and about 2.85 meters from the tip of the dorsal fin to the tip of the anal fin. The fish exceeded 2000 kilograms in weight. Because of the toxins the flesh contains, the species has no commercial value in the Gaza Strip. The fish seemed to be intensively parasitized because of the magnitude of long tape-worms exiting alive from their mouths. Fishery by-catch, and floating litter were main threats facing the Ocean Sunfish locally. From a conservation point of view, the authors recommend to enhancing ecological awareness campaigns among Gaza fishermen and other Palestinian sectors to avoid fishing and consuming of this non-edible and ecologically important fish species.

\section{Mini Review}

The Ocean Sunfish or Common Sunfish or Common Mola (Mola mola, Linnaeus 1758) belongs to the Molidae family and Tetraodontiformes order (e.g. pufferfish, triggerfish, boxfish)
$[1,2]$. Sunfishes seem to be so called because of their habit of drifting at the surface as if basking in the sun. Currently, four species are recognized: The Ocean Sunfish (Mola mola, Linnaeus 
1758); Slender Sunfish (Ranzania laevis, Pennant 1776); Sharptailed Sunfish (Masturus lanceolatus, Liénard 1840) and Short Sunfish (Mola ramsayi, Giglioli 1883) in addition to two other Mola species A and C waiting formal scientific naming [3]. Despite its worldwide occurrence in temperate and tropical seas [4], the Ocean Sunfish is well known to scientific parties and fishermen of most Mediterranean countries as the heaviest and largest bony fish worldwide [5]. It can grow up to a length of $2.7 \mathrm{~m}$ and weigh 2.3 tons $[2,6]$. It has a body which is flattened laterally. The most obvious physical characteristic of the fish is the replacement of its caudal fin by a broad, stiff lobe called the pseudocaudal fin or clavus which plays as a rudder. Sims et al. $[7,8]$ pointed out that despite the lack of caudal propulsion of the Ocean Sunfish; it remains a powerful swimmer capable of highly directional horizontal movements, deep-water dives and even breaching.

In this bizarre morphology (Figure 1), the fish resembles a half fish thus, having the description of a swimming head [9]. The fish is also characterized by its powerful dorsal and anal fins that seem to be the primary means of locomotion. The slow locomotion rhythm of the Ocean Sunfish makes it subject to large predators, such as large sharks, orcas (Killer Whales) and sea lions [10,11]. The fish may dive below the thermocline to avoid predators [12]. It is well known for the Ocean Sunfish to spend up considerable time of the day basking in the sun near the surface of the water; a behavior aiming at re-warming their bodies up after deep water dives to hunt [12-14]. Another hypothesis for sun basking behavior of the fish is ectoparasite elimination as pointed out by Abe, et al. [15] and Abe et al. [16,17]. Although the wide-ranging Ocean Sunfish is a generalist predator in the sense that it consumes a broad food items including small fishes, squids and other mollusks, zooplankton, crustaceans and brittle stars, it is well known as an obligate gelativore, feeding on dangerous jellyfishes (phylum Cnidaria or Coelentrata) prevailing at marine ecosystems and causing harm to swimmers and people [18-23].

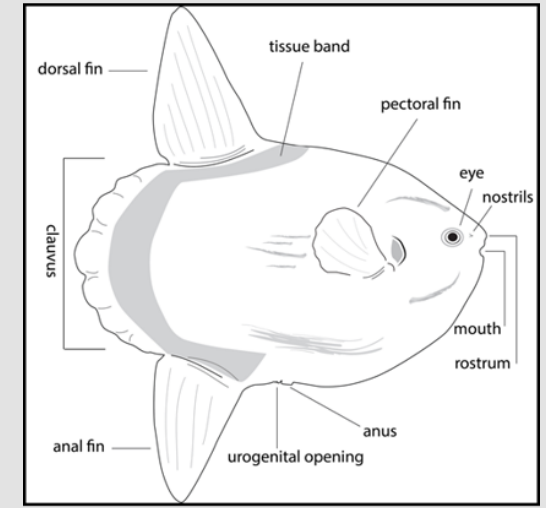

Figure 1: The unique body structure of the Ocean Sunfish (Mola mola) [17].

The jellyfish food item may lead them to ingest plastic debris accidentally. The Ocean Sunfish is not a commercially important fish although there is some market for it in some Asian countries [24]. From a conservation point of view, the Ocean Sunfish is subject to extremely high level of incidental by-catch in the global fisheries including the Mediterranean fisheries [12,25,26]. The Ocean Sunfish and other Mola species were recorded in the marine waters around the world including the Mediterranean Sea, Red Sea and Middle East countries [10,25,27-38]. Although the Gaza Strip (365 km2) is a small piece of land lying at the southwestern coast of Palestine on the Mediterranean Sea, its 42-km beaches experienced from time to time discarded or stranded specimens of the Ocean Sunfish, having various sizes. The key aim of this paper is to provide information on Ocean Sunfishes (Mola mola) caught off the Mediterranean coast of the Gaza Strip, Palestine. In fact, the fish is rarely seen in the Palestinian marine waters because of its solitary and erratic habits in spite of the fact that it is the most frequently encountered Mola species worldwide [39]. The importance of the current study comes from the fact that it is the first study dealing with the Ocean Sunfish in Palestine.

\section{Materials and Methods}

\section{The Gaza Strip}

The Gaza Strip $\left(31^{\circ} 25^{\prime} \mathrm{N}, 34^{\circ} 20^{\prime} \mathrm{E}\right)$ is an arid to semi-arid strip of the Palestinian land along the southeastern Mediterranean (Figure 2), having an area of $365 \mathrm{~km} 2$, and a population of about 2.0 million, of whom the majority are United Nations-registered refugees. The Gaza Strip is one of the most densely populated places in the world [40]. It has a total number of about 3,500 fishermen working on about 1,000 fishing vessels of different sizes and capacities [41]. The total production of fisheries resources is about 3,480 tons per year. The accessibility and exploitation of Gazan fishermen to the fluctuating fishing area is often governed by the Israeli occupation. 
The Directorate General of Fisheries Ministry of Agriculture, is the competent, responsible and authorized authority to ensure the maximum utilization of fishery resources in the Palestinian Territories [42].

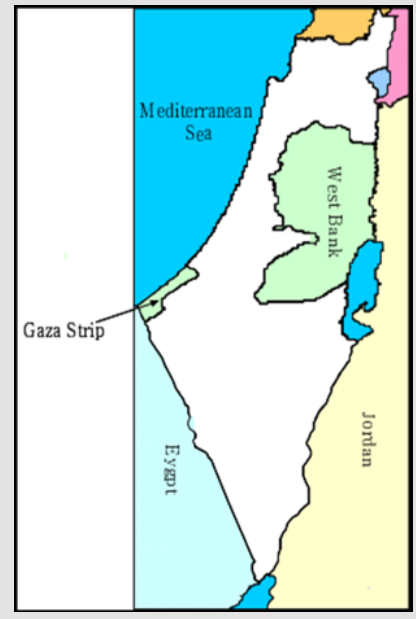

Figure 2: Location of the Gaza Strip at the southwestern corner of Palestine.

\section{Procedure}

The current study is cumulative and descriptive in its style, extending for 15 years starting from 2006 to 2020. During this long period of time, frequent regular and irregular visits have been carried out to the coast of the Gaza Strip which extends about $42 \mathrm{~km}$ along the Mediterranean Sea, Gaza Fishing Harbor and fish markets in an attempt to study marine biota and environment. Meetings and discussions with the staff of the Directorate General of Fisheries, Ministry of Agriculture, Gazan fishermen and even normal people visiting the Mediterranean beaches of the Gaza Strip have been carried out to fill the gaps needed in data collection concerning fish fauna, of which the Ocean Sunfish is a capital part. During the study period, data have been gathered from the stakeholders regarding the sighting, stranding and by-catch of the Ocean Sunfish. Moreover, the local media reports regarding the fish have been chased by the authors to get any sort of information of the fish in question. The authors conducted on-site visits for some discarded or stranded specimens of the Ocean Sunfish to take approximate measurements and available notes. Finally, professional digital cameras have been used throughout the study period and photos have been taken for documentary and confirmatory purposes. Photos of discarded Ocean Sunfishes were taken as well from the electronic Palestinian media resources.

\section{Results and Discussion}

\section{The Marine Ecology of the Gaza Strip}

Since the Introduction of the Palestinian National Authority to Palestine (West Bank and Gaza Strip) in 1994, more focus was paid by the environmental bodies to the marine ecosystem of the Gaza Strip, which was totally neglected during the era of Israeli Occupation. Studies on the marine ecology of the Gaza Strip, in spite of their rarity, were carried out in an atmosphere characterized by a total absence of specialists in such marine disciplines and a total presence of anthropogenic stresses facing the marine environment and fishery resources. As a result, marine fauna was rarely surveyed or studied by the Palestinian scientific parties $[40,41,43,44]$. In the last couple of years, works on marine fishes were carried out and gave considerable data. More recently, Abu Amra [45] conducted a modest study and surveyed as many as 128 bony fish species occurring in the marine ecosystem of the Gaza Strip, of which the Ocean Sunfish was the largest fish species encountered.

Shaheen [46] carried out a study dealing with pisciculture projects of the Gaza Strip and gave a list of some marine fishes of the Gaza Strip. Abu Aouda et al. [47] carried out a preliminary survey of ichthyofauna prevailing at the marine ecosystem of the Gaza Strip. The studies of Abd Rabou et al. [43] and Abd Rabou [44] mentioned short notes on the non-target marine fauna accidently fallen in the gill nets of Gazan fishermen, of which the Ocean Sunfish and the threatened sea turtles; namely the Loggerhead Sea Turtle (Caretta caretta), Green Sea Turtle (Chelonia mydas) and the Leatherback Sea Turtle (Dermochelys coriacea), were a capital part. Brochures of fish fauna were produced in 2012 by the Directorate General of Fisheries, Ministry of Agriculture [48]. None of the previous mentioned studies had special focus on the Ocean Sunfish in spite of its intermittent occurrence at the Mediterranean waters of the Gaza Strip. 


\section{Occurrence and Local Accidental Catch of Ocean} Sunfish

Knowledge on the occurrence of the Ocean Sunfish at the Mediterranean coast of the Gaza Strip is increasingly growing scientifically and in the field. Abd Rabou et al. [43], Abd Rabou [44] and Abu Amra [45] ensured the occurrence of the species among the ichthyofauna of the Gaza Strip. A good fraction of Gazan fishermen was found to be aware of the Ocean Sunfish and its ecological role in the marine environment (Personal Communications). Although the Slender Sunfish (Ranzania laevis) and the Short Sunfish (Mola ramsayi) were recorded at the Kuwait and Omani waters [27,32], they have never been recorded among the Mediterranean fishes of the Gaza Strip [45]. At least, 20 specimens of the species were known to be separately caught off the Mediterranean coast of the Gaza Strip by drift gill nets since 2006, i.e. during the last 15 years. The heaviest specimen was recorded in December 12, 2006 (Figure $3)$. The on-site discussion with local people including fishermen revealed that the fish was so heavy to the extent that 20 men tried to pull it out from the water, but they failed $[49,50]$. At the global level, Sunfishes are accidentally but frequently caught in drift gillnet fisheries, making up nearly $30 \%$ of the total catch of the swordfish fishery employing drift gillnets in California.

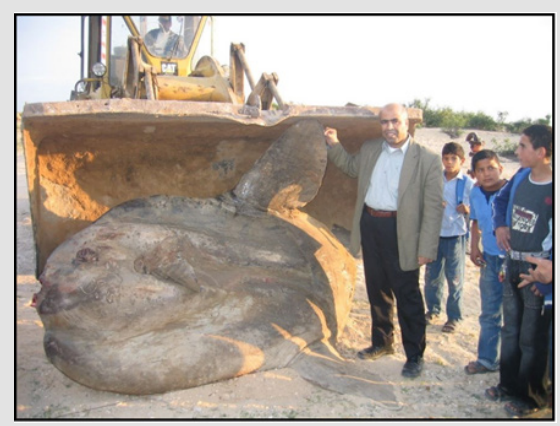

Figure 3: An ocean sunfish caught off the Mediterranean coast of the Gaza Strip, Palestine in December 12, 2006 measuring about $2.8 \mathrm{~m}$ in length and about 2 tons in weight.

The fish comprised 70\% - 93\% of the total fish catch in Spanish drift gillnet fisheries within the Mediterranean between 1992 and 1994 [25]. The frequency of observation of Ocean Sunfishes by the authors and fishermen was none, once or twice per year. Most of specimens were caught during the cooler months of the year extending from November to April (Figure 4). This could be attributed to the accidental by-catch of the fish during its upward movement in order to exert sun basking as a behavior trying to elevate its internal temperature after diving in cold deep waters
[51]. According to Fulling et al. [52], Ocean Sunfishes were sighted with greatest frequency during the winter (December - April) in sea surface temperature $<24^{\circ} \mathrm{C}$. They attributed such sightings in winter to the basking behavior which is commonly associated with thermoregulation in addition to the oxygen replenishment after long, deep dives to oxygen-deficient depths. Sun basking could be related to ectoparasite elimination as well [15]. Figure 4 illustrates some of the discarded Ocean Sunfishes caught off the Mediterranean coast of the Gaza Strip.

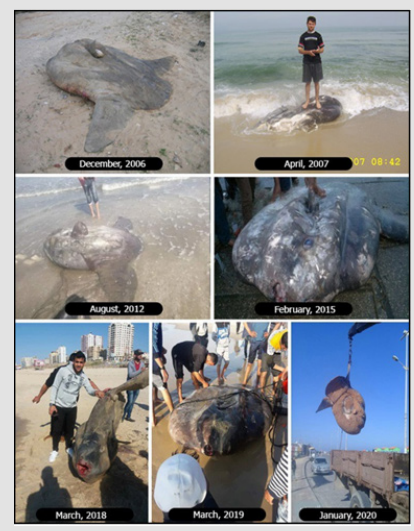

Figure 4: Some of the discarded Ocean Sunfishes caught off the Mediterranean coast of the Gaza Strip, Palestine. 


\section{General Description of Ocean Sunfish}

Many discarded and stranded Ocean Sunfishes have been seen by the authors at the Mediterranean coast of the Gaza Strip. However, the first description and measurements were made on the largest and heaviest specimen caught off the Mediterranean coast on December 12, 2006 (Figure 3). Generally, the specimen had a laterally compressed body, which has three regions: Head, trunk and pseudo-tail (clavus). Both the dorsal and anal fins have multiple soft rays without spines. They protrude prominently from the posterior part of the body. The pectoral fins are small and rounded. The pelvic fins are absent. The operculum (gill opening) lies behind the eyes directly. The eyes are relatively small compared to the size of the fish's body. The mouth, which is small, is difficult to close, and has fused teeth that form a beak. The scaleless skin, which is brown, is mostly rough having varied thickness. The color is often darker on the dorsal surface, fading to a lighter shade ventrally. Sunfishes can be as tall as they are long when their dorsal and anal or ventral fins are extended (Figure 1).

On-sites morphometric measurements pointed out that the
Ocean Sunfish measured about 2.8 meters from the head to the pseudo-tail as a total length (TL), and about 2.85 meters from the tip of the dorsal fin to the tip of the anal fin. The anal fin looks slightly higher than the dorsal fin (the height of both dorsal and anal fins was measured vertically from the base to the distal tip of each fin). The available approximate morphometric measurements of the Ocean Sunfish caught off the Mediterranean coast of the Gaza Strip on December 12, 2006 were illustrated in Table 1. The fish seemed to exceed 2000 kilograms (2 tons) in weight. Because of this heavy weight, a tractor was called to pull the fish out on the beach of Khan Younis in southern Gaza Strip (Figure 3). The fish was a strange marine creature to local people; especially children in the sense that it resembles a fish head without a tail. The approximate morphometric measurements taken for the fish in the current study constituted a part of the real measurements taken for the same fish worldwide. Moreover, the different lengths and sizes generally give different morphometric and even meristic measurements, as indicated by various studies concerning the Ocean Sunfish $[27,30,32,38]$ (Table 1 ).

Table 1: Some approximate and initial morphometrics of the largest Ocean Sunfish caught off the Mediterranean coast of the Gaza Strip on December 12, 2006.

\begin{tabular}{|c|c|}
\hline Morphometric Characters & Approximate Measurements (cm) \\
\hline $\begin{array}{c}\text { Total length (measured horizontally from the tip of the mouth to the end } \\
\text { of the cla } \text {-vus) }\end{array}$ & 280 \\
\hline The distance between the tips of dorsal and anal fins & 285 \\
\hline Distance between bases of dorsal and anal fins & 173 \\
\hline Height of dorsal fin & 132 \\
\hline Height of anal fin & 140 \\
\hline Pre-dorsal fin length & 162 \\
\hline Pre-anal fin length & 148 \\
\hline Body depth (measured vertically at the widest points of the body margin) & 196 \\
\hline
\end{tabular}

\section{Local Consumption of Ocean Sunfish}

Ocean Sunfishes are considered a delicacy in some parts of the world such as Japan, Korea, and Taiwan. They are used in traditional Chinese medicine as well [24]. In the European Union, regulations have been issued to ban the sale of fish and fishery products derived from the Molidae family. The cause of ban was attributed to the fact that these fishes contain toxins distributing in their bodies. The toxins were known to be harmful to human health. The repeated catch of the fish off the Mediterranean coast of the Gaza Strip made the local fisheries and scientific parties carrying out campaigns to interpret the toxicity of the fish to the public. In fact, the strange appearance, thickness of skin and toxicity of the fish made it excluded from edibility by Gazans. Similarly, the high toxicity of the Silver-cheeked Toadfish (Lagocephalus sceleratus) caught off the Mediterranean coast of the Gaza Strip resulted in tens of poisoning and hospitalized cases. Such a tragedy made the responsible parties to conduct awareness campaigns aiming at preventing the sale and consumption of the fish in question [42].

\section{Parasitic Load of Ocean Sunfish}

Additional striking event, associated with the Ocean Sunfishes caught off the Mediterranean coast of the Gaza Strip on December, 2006 and March, 2018 was the long tape-worms (cestodes) coming out alive from their mouths which indicated that the fishes were intensively parasitized. Similar results were revealed by Schwartz et al. [13] who pointed out that the parasites which very likely caused the death of Ocean Sunfishes have remained alive for at least 17 hours after the removal of the specimens from the water. Although the releasing tapeworms (Figure 5) were not scientifically identified, they were measured in meters and their proglottids (segments) were apparent by naked eyes. According 
to Gustinelli et al. [53], various round worms (nematodes) and flat worms (platyhelminthes) were found to inhabit the liver and other organs of the stranded specimens of Ocean Sunfishes. The flatworm Accacoelium contortum is one of the most Ocean Sunfish parasites and has been reported in the Mediterranean Sea, the Northeast Atlantic Ocean and the South Pacific.

In a study carried out in Spain, $47.2 \%$ of 106 sunfish examined were found to host Accacoelium contortum [54]. The ectoparasites and endoparasites of the fish motivate it to seek relief in a number of ways. The breaching behavior of the Ocean Sunfish and the intense cleaning efforts of various marine organisms markedly reduced the initially severe ectoparasite loads including the attached copepods and trematodes [55]. Barreiros, et al. [56] encountered the Goose Barnacle (Lepas anatifera), which is a Cirriped belonging to phylum Arthropoda, attaching to the esophagus of the Ocean Sunfish. Such association may cause feeding problems since the attachment of this Cirriped may obstruct the fish's esophagus. Such parasites may cause diseases to Ocean Sunfishes and end their lives (Figure 5).

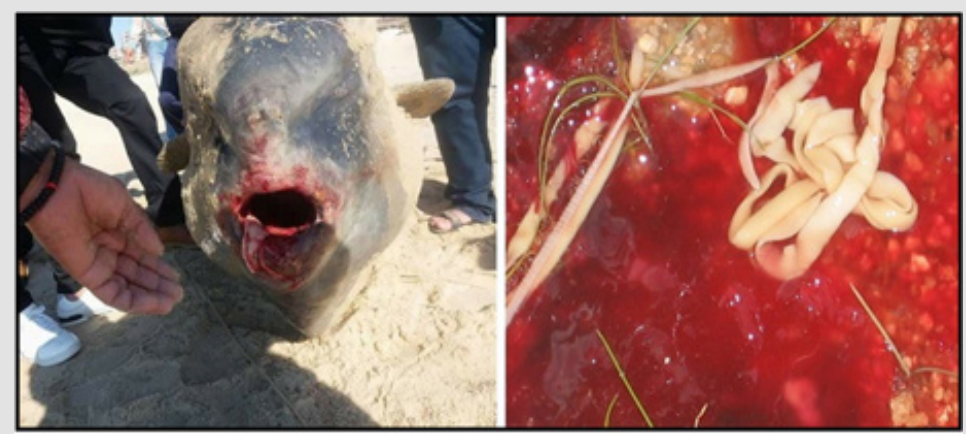

Figure 5: The intensive amount of tapeworms exiting the mouths of Ocean Sunfishes, caught off the Mediterranean coast of the Gaza Strip, indicating their high infestation with internal parasites.

\section{Local Threats Facing Ocean Sunfishes}

The fishery by-catch, and destruction of the Ocean Sunfish are unregulated events worldwide. It is well supposed that the fishery by-catch, and discards are increasing with increase of fishing efforts and enhanced production as well $[25,52]$. The population of the species is considered as Vulnerable (VU) in IUCN Red Lists category [57]. In the marine ecosystem of the Gaza Strip, the threats imposed on the species seem to coincide with those prevailing around the world. The Ocean Sunfish are likely being hit by boats and being caught as by-catch in fishing gear used by Gazan fishermen. The floating litter; particularly plastic bags which resemble jellyfish, a common prey item of Ocean Sunfishes, forms another threat in the marine environment. The sources of such solid waste items were known to come from the Palestinian fishery fleet, local beach establishments like resorts and shops, and raw or semi-treated wastewater discharged in big quantities into the Mediterranean coast [41].

In this regard, Wadi Gaza is one of the main wastewater discharging points into the Mediterranean along the coast of the Gaza Strip [58]. Nylon bags can choke and suffocate the Ocean Sunfish and other marine biota like sea turtles or fill their stomach to the extent that they starve [59]. Although the process in not practiced in the Gaza Strip, the Ocean Sunfish were found to be fined by fishermen in some areas of the world. This process, in which the fins are cut off, results in the eventual death of the fish, because it can no longer propel itself without its dorsal and anal fins. A decrease in sunfish populations may be caused by increasing popularity of sunfish in human diet as previously mentioned in some Asian countries [24]. Such a popularity seems to be absent in the Mediterranean basin including the very small piece of land represented by the Gaza Strip of Palestine.

\section{Local Conservation of Ocean Sunfish}

Ocean sunfishes are found in all the oceans of the world, excluding the icy polar seas. Although the IUCN has listed the Ocean Sunfish as "Vulnerable" at the global level [57,60], they are not targeted for human consumption in the Gaza Strip. Otherwise, they are endangered by by-catch. In spite of the claim that many fishermen used the flesh of the fish for feeding purposes, the majority were aware of the non-palatability of fish's flesh because of the toxins prevailing in its tissues. Nowadays, there is enough and escalating awareness among the Gazan fishermen concerning the conservation of the Ocean Sunfishes due to their unique ecological role and balance in the marine environment. The fate of discarded or stranded specimens of the Ocean Sunfish is burial on the beach or disposal of in the solid waste landfills located in the eastern parts of the Gaza Strip. From a preservation point of view, the Ocean Sunfish has never been found as a preserved specimen in the biological exhibitions of local universities and the small museum of the Directorate General of Fisheries, Ministry of Agriculture. This could be attributed to the fact that the Ocean Sunfish is the largest bony fish globally $[2,6]$ and the locally available capabilities in terms of preservation techniques, preservation material and spaces cannot 
in any way support the preservation of such large specimens. The potential of Palestinian universities in the Gaza Strip is minimal and is limited to preserving some biological samples of small sizes.

\section{Recommendations}

Finally, the authors recommend to enhancing ecological awareness process of Gaza fishermen to avoid fishing of this nonpalatable and ecologically important fish species. Moreover, there is a need to investigate the frequency of occurrence, biology and ecology of the Ocean Sunfish and other molids (if any) at the Mediterranean coast of the Gaza Strip, Palestine.

\section{Acknowledgement}

Our thanks are due to Ms. Eqbal S. Radwan, Mr. Ismail S. Radwan and Mr. Bashar S. Jarayseh for their technical support throughout the current study.

\section{Conflicts of Interest}

The authors declare that there are no conflicts of interest regarding the publication of this article.

\section{References}

1. Bass AL, Dewar H, Thys T, Streelman JT, Karl SA (2005) Evolutionary divergence among lineages of the Ocean Sunfish family, Molidae (Tetraodontiformes). Marine Biology 148(2): 405-414.

2. Pope EC, Hays GC, Thys TM, Doyle TK, Sims DW, et al. (2010) The biology and ecology of the ocean sunfish (Mola mola): A review of current knowledge and future research perspectives. Reviews in Fish Biology and Fisheries 20: 471-487.

3. Sawai E, Yamanoue Y, Yoshita Y, Sakai Y, Hashimoto H (2011) Seasonal occurrence patterns of Mola sunfishes (Mola spp. A and B; Molidae) in waters off the Sanriku region. Japanese Journal of Ichthyology 58(2): 181-187.

4. Houghton JD, Doyle TK, Davenport J, Hays GC (2006) The Ocean Sunfish (Mola mola): Insights into distribution, abundance and behavior in the Irish and Celtic Seas. Journal of the Marine Biological Association of the United Kingdom 86: 1237-1243.

5. Abdul Malak DA, Livingstone SR, Pollard D, Polidoro BA, Cuttelod A, et al (2011) Overview of the conservation status of the marine fishes of the Mediterranean Sea. IUCN.

6. Pan H, Yu H, Ravi V, Li C, Lee AP, et al. (2016) The genome of the largest bony fish, ocean sunfish (Mola mola), provides insights into its fast growth rate, GigaScience 5(1): 1-12.

7. Sims DW, Queiroz N, Doyle TK, Houghton JD, Hays GC (2009) Satellite tracking of the World's largest bony fish, the Ocean Sunfish (Mola mola L.) in the North East Atlantic. Journal of Experimental Marine Biology and Ecology 370(1-2): 127-133.

8. Sims DW, Queiroz N, Humphries NE, Lima FP, Hays GC (2009) Long-term GPS tracking of Ocean Sunfish (Mola mola) offers a new direction in fish monitoring. PLoS One 4(10): e7351.

9. Thys T (1994) Swimming heads. Natural History 103(8): 36-39.

10. Fergusson IK, Compagno LJ, Marks MA (2000) Predation by White Sharks (Carcharodon carcharias) (Chondrichthyes: Lamnidae) upon chelonians, with new records from the Mediterranean Sea and a first record of the Ocean Sunfish (Mola mola) (Osteichthyes: Molidae) as stomach contents. Environmental Biology of Fishes 58: 447-453.
11. Thys TM, Ryan JP, Dewar H, Perle CR, Lyons K, et al. (2015) Ecology of the Ocean Sunfish (Mola mola) in the southern California Current System. Journal of Experimental Marine Biology and Ecology 471: 64-76.

12. Cartamil DP, Lowe CG (2004) Diel movement patterns of Ocean Sunfish (Mola mola) off southern California. Marine Ecology Progress Series 266: 245-253.

13. Schwartz FJ, Lindquist DG (1987) Observations on Mola basking behavior, parasites, echeneidid associations, and body-organ weight relationships. Journal of the Elisha Mitchell Scientific Society 103(1): $14-20$.

14. Thums M, Meekan M, Stevens J, Wilson S, Polovina J (2013) Evidence for behavioral thermoregulation by the world's largest fish. Journal of the Royal Society Interface 10(78): 20120477.

15. Abe T, Sekiguchi K (2012) Why does the Ocean Sunfish bask? Communicative \& Integrative Biology 5(4): 395-398.

16. Abe T, Sekiguchi K, Onishi H, Muramatsu K, Kamito T (2012) Observations on a school of Ocean Sunfish and evidence for a symbiotic cleaning association with albatrosses. Marine Biology 159(5): 1173-1176.

17. Coward MA (2017) Answering the mysteries of the Mola mola (Ocean Sunfish).

18. Arai MN (2005) Predation on pelagic coelenterates: A review. Journal of the Marine Biological Association of the United Kingdom 85: 523-536.

19. Houghton JDR, Doyle TK, Wilson MW, Davenport J, Hays GC (2006) Jellyfish aggregations and Leatherback Turtle foraging patterns in a temperate coastal environment. Ecology 87(8): 1967-1972.

20. Hays GC, Farquhar MR, Luschi , Teo SLH, Thys TM (2009) Vertical niche overlap by two ocean giants with similar diets: Ocean Sunfish and Leatherback Turtles. Journal of Experimental Marine Biology and Ecology 370: 134-143.

21. Dewar H, Thys T, Teo SLH, Farwell C, O’Sullivan J, et al. (2010) Satellite tracking the world's largest jelly predator, the Ocean Sunfish, Mola mola in the Western Pacific. Journal of Experimental Marine Biology and Ecology 393: 32-42.

22. Boero F (2013) Review of jellyfish blooms in the Mediterranean and Black Sea: Studies and Reviews. General Fisheries Commission for the Mediterranean, No. 92, Rome, FAO, p. 53.

23. Nakamura I, Sato K (2014) Ontogenetic shift in foraging habit of Ocean Sunfish (Mola mola) from dietary and behavioral studies. Marine Biology 161: 1263-1273.

24. Liu KM, Lee ML, Joung SJ, Chang YC (2009) Age and growth estimates of the Sharptail Mola (Masturus lanceolatus) in waters of eastern Taiwan. Fisheries Research 95(2-3): 154-160.

25. Silvani L, Gazo M, Aguilar A (1999) Spanish driftnet fishing and incidental catches in the western Mediterranean. Biological Conservation 90(1): 79-85.

26. Potter IF, Howell WH (2011) Vertical movement and behavior of the Ocean Sunfish Mola mola in the northwest Atlantic. Journal of Experimental Marine Biology and Ecology 396(2): 138-146.

27. Al Baz AF, Bishop JM, Hamza B (1999) First Arabian Gulf records of Molidae from Kuwait. Kuwait Journal for Science and Technology 26(2): 315-320.

28. Sims D, Southall E (2002) Occurrence of Ocean Sunfish (Mola mola) near fronts in the western English Channel. Journal of the Marine Biological Association of the UK 82(5): 927-928.

29. Nakatsubo T, Kawachi M, Mano N, Hirose H (2007) Spawning period of Ocean Sunfish (Mola mola) in water of the eastern Kanto region, Japan. Aquaculture Science 55(4): 613-618.

30. Pastore MA (2008) Necropsy of an Ocean Sunfish stranded along the 
Taranto coast (Apulian, south Italy). Cambridge University Press.

31. Potter IF, Galuardi B, Howell WH (2011) Horizontal movement of Ocean Sunfish (Mola mola) in the northwest Atlantic. Marine Biology 158(3): 531-540.

32. Jawad LA (2013) First documented record of the Ocean Sunfish, Mola mola (Linnaeus), from the Sea of Oman, Sultanate of Oman (Teleostei: Molidae). Stuttgarter Beiträge zur Naturkunde A 6: 287-290.

33. Yasemi M, Nazari Bejgan AR (2014) The first record of Southern Ocean Sunfish (Mola ramsayi) from Northern Oman Sea, Iran. Iranian Journal of Fisheries Sciences 13(1): 242-246.

34. Dulcic J, Beg Paklar G, Grbec B, Morovic M, Matic F, et al. (2007) On the occurrence of Ocean Sunfish Mola mola and Slender Sunfish Ranzania laevis in the Adriatic Sea. Journal of the Marine Biological Association of the United Kingdom 87(3): 789-796.

35. Öztürk RÇ, Özbulut E (2016) First record of the ocean sunfish, Mola mola (Linnaeus 1758), from the Black Sea. Journal of the Black Sea / Mediterranean Environment 22(2): 190-193.

36. Sousa LL, Queiroz N, Mucientes G, Humphries NE, Sims DW (2016) Environmental influence on the seasonal movements of satellitetracked Ocean Sunfish (Mola mola) in the north-east Atlantic. Animal Biotelemetry 4(7): 1-19.

37. FAO (2018) The state of Mediterranean and Black Sea fisheries. General Fisheries Commission for the Mediterranean, Rome, pp. 172.

38. Amer MA, El Sadek A, Fathallah A, Omar HA, Eltoutou MM (2019) First record for the Sunfish Mola mola (Molidae: Tetraodontiformes) from the Egyptian coasts, Aqaba Gulf, Red Sea, with notes on morphometrics and levels of major skeletal components. Egyptian Journal of Aquatic Biology \& Fisheries, 23(2): 563-574.

39. Santini F, Tyler JC (2002) Phylogeny of the Ocean Sunfishes (Molidae, Tetraodontiformes), a highly derived group of teleost fishes. Italian Journal of Zoology 69(1): 37-43.

40. UNEP (2003) Desk study on the environment in the Occupied Palestinian Territories. United Nations Environment Program (UNEP), Nairobi, Kenya, pp. 188.

41. Al Hmaidi MS (2001) Gaza Coastal and marine environmental protection and management action plan. Ministry of Environmental Affairs (MENA), Palestinian National Authority, Gaza City (Palestine), pp. 112.

42. Abd Rabou AN (2019) On the occurrence and health risks of the Silvercheeked Toadfish (Lagocephalus sceleratus Gmelin, 1789) in the marine ecosystem of the Gaza Strip - Palestine. Biodiversitas 20(9): 2618-2625.

43. Abd Rabou AN, Yassin MM, Saqr TM, Madi AS, El Mabhouh FA, et al. (2007) Threats facing the marine environment and fishing in the Gaza Strip: Field and literature study. Islamic University of Gaza, p. 11-31.

44. Abd Rabou AN (2013) Priorities of scientific research in the fields of marine environment and fishery resources in the Gaza Strip - Palestine. Priorities of Scientific Research in Palestine: Towards a National Directory of Scientific Research, March 25-26, 2013, Scientific Research Affairs, Islamic University of Gaza, Gaza Strip, Palestine, pp. 481-522.
45. Abu Amra HE (2018) A survey of marine bony fishes of the Gaza Strip, Palestine. [M.Sc. Thesis], Department of Biology, Islamic University of Gaza, Gaza Strip - Palestine, pp. 110.

46. Shaheen AL (2016) Assessment of pisciculture status in the Gaza Strip. M.Sc. Thesis, Department of Biological Sciences, Al-Azhar University Gaza, Palestine, pp. 163

47. Abu Aouda SA, Abu Aouda LM, Zuhud NH (2008) A preliminary survey of marine fishes in the Gaza Strip. B.Sc. Dissertation, Department of Biology, Islamic University of Gaza, Palestine.

48. Salah JY, Abutair ME (2012) Common fishes of the Gaza Strip: Brochures designated by the Directorate General of Fisheries, Ministry of Agriculture, Palestinian National Authority.

49. Elaph (2006) The largest and strangest fish in the world at the beach of Gaza.

50. Khalaf NA (2013) An Ocean Sunfish or Common Mola (Mola mola Linnaeus, 1758) caught off the coast of Gaza: The first record from Palestine, East Mediterranean Sea. Fauna Palaestina, Part III: Zoological studies in Palestine between 2005-2012, Al-Jundi Publication House, Jerusalem, Palestine, pp. 265-285.

51. Nakamura I, Goto Y, Sato K (2015) Ocean Sunfish rewarm at the surface after deep excursions to forage for siphonophores. Journal of Animal Ecology 84(3): 590-603.

52. Fulling GL, Dagma F, Knight K, Hoggard W (2007) Distribution of Molidae in the northern Gulf of Mexico. Gulf and Caribbean Research 19(2): 5367.

53. Gustinelli A, Nardini G, Aureli G, Trentini M, Affronte M, et al. (2006) Parasitofauna of Mola mola (Linnaeus, 1758) of the Italian seas. Mediterranean Marine Biology 13: 872-876.

54. Ahuir Baraja AE, Padrós F, Palacios Abella JF, Raga JA, Montero FE (2015) Accacoelium contortum (Trematoda: Accacoeliidae): A trematode living as a monogenean: Morphological and pathological implications. Parasites \& Vectors 8: 540.

55. Konow N, Fitzpatrick R, Barnett A (2006) Adult Emperor Angelfish (Pomecanthus imperator) clean Giant Sunfishes (Mola mola) at Nusa Lembongan, Indonesia. Coral Reefs 25(2): 208.

56. Barreiros JP, Teves M (2005) The Sunfish Mola mola as an attachment surface for the Lepadid Cirriped Lepas anatifera - a previously unreported association. Aqua, Journal of Ichthyology and Aquatic Biology 10(1): 1-4.

\section{IUCN (2015) IUCN Red List of Threatened Species.}

58. Abd Rabou AN (2005) An ecological survey and assessment of Wadi Gaza Nature Reserve, Gaza Strip - Palestine, with particular emphasis on wildlife, Ph.D. thesis, Department of Environmental Studies, Faculty of Science and Technology, School of Life Sciences, Al-Neelain University - Sudan, pp. 278.

59. Barreiros JP, Barcelos J (2001) Plastic ingestion by a Leatherback Turtle (Dermochelys coriacea). Marine Pollution Bulletin 42(11): 1196-1197.

60. ThoughtCo (2020) Ocean Sunfish facts. 
ISSN: 2574-1241

DOI: 10.26717/BJSTR.2020.29.004831

Abdel Fattah N Abd Rabou. Biomed J Sci \& Tech Res

(c) (P) This work is licensed under Creative Commons Attribution 4.0 License

Submission Link: https://biomedres.us/submit-manuscript.php

\begin{tabular}{ll} 
BIOMEDICAL & Assets of Publishing with us \\
RESEARCHES & - Global archiving of articles \\
& - Immediate, unrestricted online access \\
\hline - Rigorous Peer Review Process
\end{tabular}

